\title{
The Distribution of Taeniophallus nicagus (Colubridae) in Suriname with Some Information on Morphology
}

\author{
Rawien Jairam \\ National Zoological Collection Suriname, Anton de Kom University, Leysweg 86, Suriname (rawien_2000@yahoo.com) \\ Photographs by the author.
}

\begin{abstract}
Taeniophallus nicagus (Colubridae) was first listed in Suriname from the Brownsberg Nature Park in 1976. Additional specimens were collected in that same year at Raleighvallen Nature Reserve on the bank of the Coppename River. Two additional locations for this species along with morphological data are provided in this paper. Apart from the number of infralabial scales, all specimens are unambiguously identified as T. nicagus. Presently this species is only known from the central part of Suriname.
\end{abstract}

The snakes of Suriname have been studied by both professional herpetologists and hobbyists. Relevant articles include Moonen et al. (1979), Hoogmoed (1982, 1985), and Abuys (2003). Surveys of previously unexplored areas in Suriname and the increased use of molecular methods have revealed new species (Fouquet et al. 2015; Jairam and Jairam-Doerga 2015, 2016; Vacher et al. 2017). Lists of snake species known to occur in Suriname are in Abuys (2003) and Claessen and Sterckstraat (2003). However, neither work mentioned Taeniophallus nicagus, although Abuys (2003) included Rhadinea brevirostris, an allied taxon into which snakes now assigned to $T$. nicagus might have been placed. We herein document the rediscovery of Taeniophallus nicagus at the Brownsberg Nature Park (BNP) and two new sites in the Nassau and Bakhuis Mountains. Taeniophallus nicagus was first mentioned for Suriname by Myers and Cadle (1994) on the basis of a specimen (Museum of Comparative Zoology, Harvard University, MCZ 149545) collected by R.A. Mittermeier in 1976 on the Voltzberg Trail, west bank of the Coppename River, in the Raleighvallen-Voltzberg Nature Reserve. Myers and Cadle (1994) resurrected the generic name Taeniophallus Cope (1895) for the Rhadinea brevirostris group. Specimens assigned to Taeniophallus nicagus differed from sympatric " $R$. brevirostris" in having an undivided sulcus spermaticus, dorsolateral cream-colored spots, and a yellow venter. Taeniophallus nicagus is also known to occur in Brazil (GBIF 2017) and French Guiana (Starace 2015). The known distribution of this species in Suriname is presently restricted to the central part of the country (Fig. 1).

\section{Material and Methods}

Three recently collected specimens of $T$. nicagus were fixed in $10 \%$ formaldehyde and stored in $70 \%$ ethanol for permanent storage at the National Zoological Collection Suriname (NZCS). The most recently collected specimen of T. nicagus in Suriname (NZCS R683) was at the Brownsberg Nature Park (BNP; $\left.4^{\circ} 56^{\prime} \mathrm{N}, 55^{\circ} 10^{\prime} \mathrm{W}\right)$ on the trail toward Leo Falls in May 2017. An earlier specimen (NZCS R658) was collected in the Nassau Mountains $\left(4^{\circ} 47^{\prime} \mathrm{N}, 54^{\circ} 35^{\prime} \mathrm{W}\right)$ in December 2016, and a juvenile (NZCS R564) was collected in the Bakhuis Mountains in October $2005\left(4^{\circ} 20^{\prime} \mathrm{N}, 56^{\circ} 44^{\prime} \mathrm{W}\right)$. The collection sites in the BNP and Bakhuis Mountains were in pristine forest, whereas that in the Nassau Mountains was in disturbed forest with dense undergrowth. The specimen from the BNP was photographed in the field before collection. Small sections of the livers from the specimens collected in the BNP and Nassau Mountains were preserved for molecular analysis. For unambiguous identification, we counted supralabials, infralabials, preoculars, postoculars, and dorsal, ventral, and caudal scales. Scale counts are compared with the information provided by Starace (2015) in Table 1. The dorsal and ventral coloration of NZCS R683 is shown in Fig. 2; Fig. 3 provides lateral and dorsal views of the head scales of the same specimen.

\section{Results}

The specimens of T. nicagus from the Nassau and Bakhuis Mountains extend the range of this species approximately 65 $\mathrm{km}$ to the east and approximately $187 \mathrm{~km}$ to the west of the 
BNP (Fig. 1). All specimens were females. A comparison of the meristic characters (Table 1 ) with the data provided by Starace (2015) shows that apart from the number of labial scales all three specimens fall within the ranges recorded for

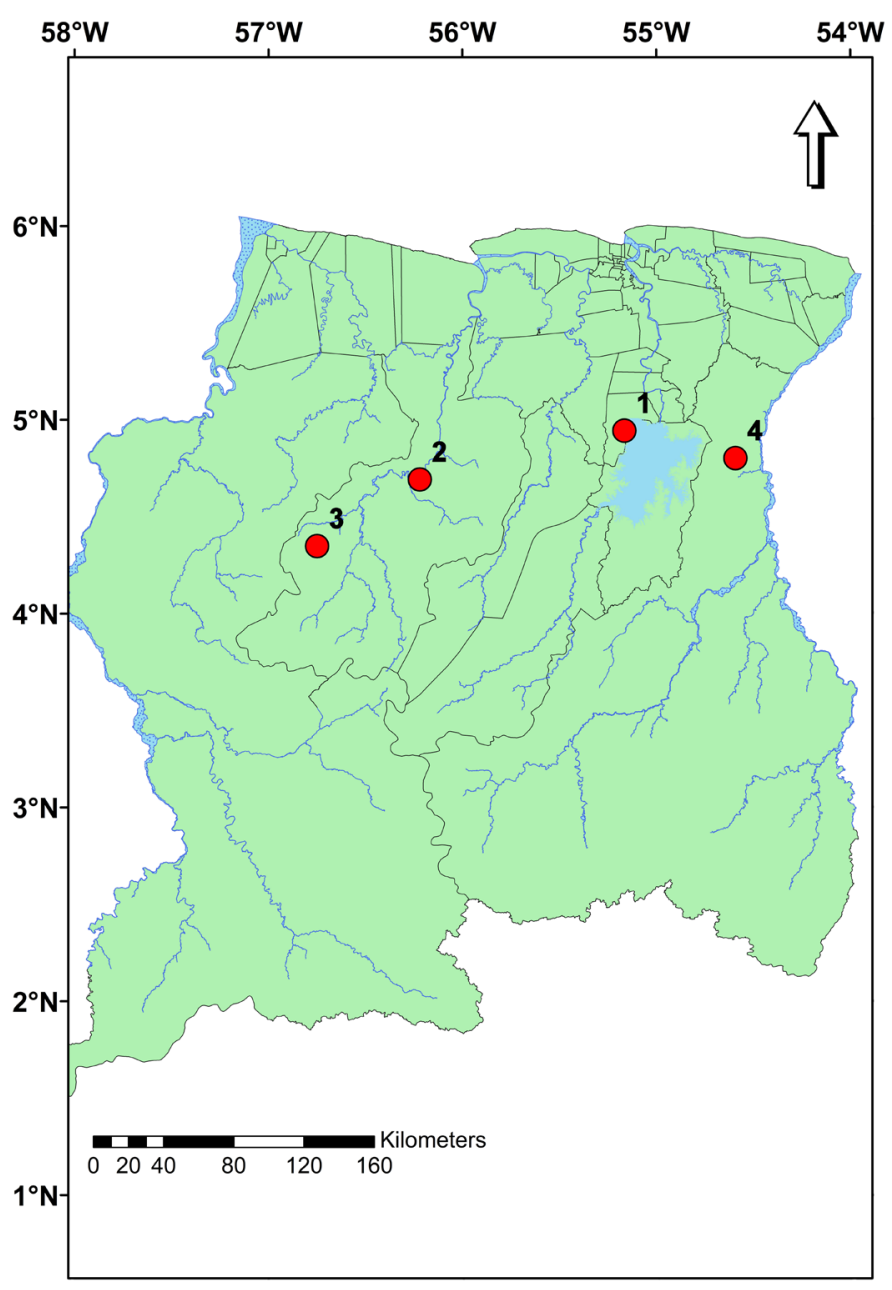

Fig. 1. Currently known localities of Taeniophallus nicagus in Suriname. Numbered locations are: (1) Brownsberg Nature Park (BNP); (2) bank of the Coppename River; (3) Bakhuis Mountains; (4) Nassau Mountains. Locations 3 and 4 are new records for this species.
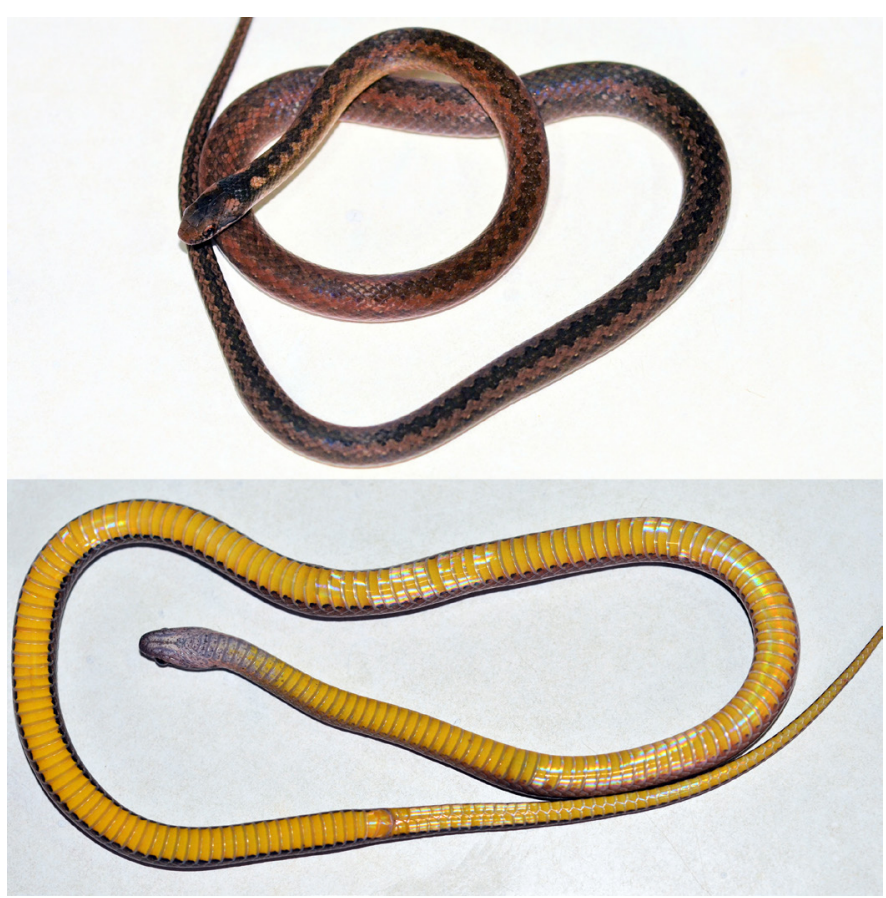

Fig. 2. Dorsal (top) and ventral views of an adult female Taeniophallus nicagus (NZCS R683) collected at the Brownsberg Nature Park (BNP) in May 2017.

this species. The dorsal color of all three specimens consists of a dark brown middorsal band bordered laterally by two cream-colored bands. The latter start anteriorly as a series of isolated spots that eventually merge to form a complete band. All specimens have two cream-colored patches on the head that barely extend onto the parietal scales (Figs. 2A \& 3B). The ventral side of the head and the throat are cream with small, scattered black spots; the venter is almost completely yellow apart from the 5 or 6 anteriormost ventrals (Fig. 2B). The lateral edges of all ventral scales are the same color as the sides; black spots, most noticeable posteriorly, form a border along the yellow ventral region. Data on the in-life ventral coloration of the specimens from the Nassau and Bakhuis Mountains are unavailable.

Table 1. A comparison of some traits from the specimens of Taeniophallus nicagus collected from the Brownsberg Nature Park (BNP), the Nassau and Bakhuis Mountains, and those described by Starace (2015).

\begin{tabular}{lcccc} 
Characters & NZCS R683 & NZCS R658 & NZCS R & Starace (2015) \\
\hline Supralabials & $8(3,4,5)$ & $8(3,4,5)$ & $8(3,4,5)$ & $7(3-5)$ or 8 (3-5) \\
\hline Infralabials & 7 & 7 & 7 & 8 to 9 \\
\hline Preoculars & 2 & 2 & 2 & 1 or 2 \\
\hline Postoculars & 2 & 2 & 17 & 2 or 3 \\
\hline Dorsals & 17 & 17 & 154 & 17 \\
\hline Ventrals & 170 & 168 & 60 (divided) & $43-72$, divided \\
\hline Caudals & 60 (divided) & $58($ divided $)$ & 180 \\
\hline
\end{tabular}




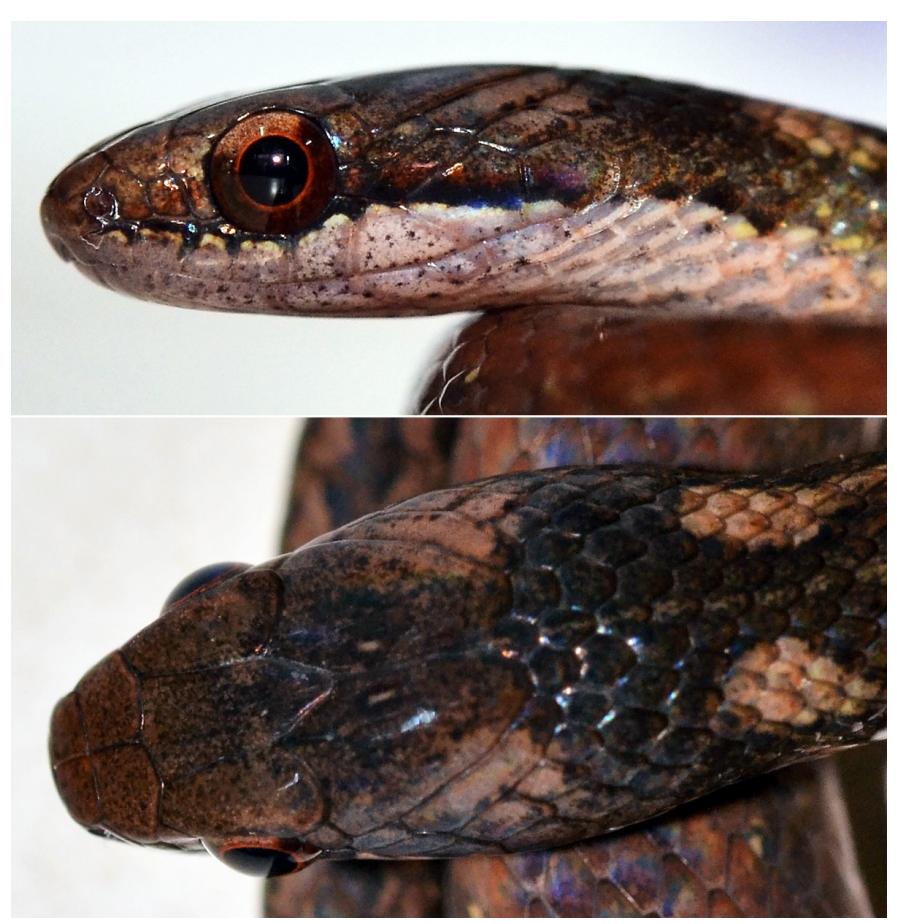

Fig. 3. Lateral (top) and dorsal views of the head of an adult female Taeniophallus nicagus (NZCS R683) collected at the Brownsberg Nature Park (BNP) in May 2017.

\section{Discussion}

Data on the herpetofaunal community in Suriname is gradually increasing as remote areas are explored and inventoried. Species that were previously listed among the nation's herpetofauna also are being reexamined as new information is published (e.g., specimens of T. nicagus previously identified as Rhadinea brevirostris). Although $R$. brevirostris and T. nicagus were thought to be sympatric by Myers and Cadle (1994), we have not collected any snakes that could be readily identified as R. brevirostris. Although Myers and Cadle (1994) removed $T$. nicagus from the " $R$. brevirostris" group, additional material and new evidence will be necessary in order to understand the relationships among these snakes.

\section{Acknowledgements}

The specimen collected from the Nassau Mountains was first observed by bird watcher Bert, who notified me of its presence on the trail.

\section{Literature Cited}

Abuys, A. 2003. De slangen van Suriname: en de andere Guyana's. Gopher Publishers, Groningen, The Netherlands.

Claessen, H. and A. Sterckstraat. 2003. De slangen van de Guyanas Deel VI. Lacerta 61: 177, 187.

Fouquet, A., V. Jean-Pierre, V. Kadosoe, P. Ouboter, and R. Jairam. 2015. Checklist of the amphibians of the Sipaliwini area, Suriname. Herpetology Notes 8: 63-68.

GBIF (Global Diversity Information Facility). 2017. Taeniophallus nicagus. <https://www.gbif.org/occurrence/search?taxon_key=2452079>.

Hoogmoed, M.S., 1982. Snakes of the Guianan region. Memórias do Instituto Butantan 46: 219-254.

Hoogmoed, M.S. 1985. Notes on the herpetofauna of Surinam IX. Xenodon werneri Eiselt, a poorly known snake from Guiana, with notes on Waglerophis merremii (Wagler) (Reptilia: Serpentes: Colubridae). Zoologische Mededelingen 59: 79-88.

Jairam, R. and S. Jairam-Doerga. 2015. First record of Amapasaurus tetradactylus Cunha, 1970 (Squamata: Gymnopthalmidae) in Suriname. Check List 11: 1-4.

Jairam, R. and S. Jairam-Doerga. 2016. Range extension and some morphological characteristics of Ptychoglossus brevifrontalis, Boulenger, 1912 (Squamata: Alopoglossidae) in Suriname. Amphibian \& Reptile Conservation 10: 30-33.

Moonen, J., W. Eriks, and K. van Deursen. 1979. Surinaamse slangen in kleur. C. Kersten \& Co., Paramaribo, Suriname.

Myers, C.W. and J.E. Cadle. 1994. A new genus for South American snakes related to Rhadinaea obtusa Cope (Colubridae) and resurrection of Taeniophallus Cope for the "Rhadinaea" brevirostris group. American Museum Novitates 3102: 1-33.

Starace F. 2015. Serpents et amphisbènes de Guyane française. Ibis Rouge Éditions, Matoury, Guyane

Vacher, J.P., P.J. Kok, M.T. Rodrigues, J.D. Lima, A. Lorenzini, Q. Martinez, M. Fallet, E.A. Courtois, M. Blanc, P. Gaucher, M. Dewynter, R. Jairam, P. Ouboter, C. Thebaud, and A. Fouquet. 2017. Cryptic diversity in Amazonian frogs: Integrative taxonomy of the genus Anomaloglossus (Amphibia: Anura: Aromobatidae) reveals a unique case of diversification within the Guiana Shield. Molecular Phylogenetics and Evolution 112: 158-173. 